\title{
SUMMER SEMINAR
}

\section{UNIVERSITY OF MONTREAL}

\author{
JUNE 26 - AUGUST 3, 1962
}

Under the sponsorship of the Canadian Mathematical Congress, a SÉMINAIRE DE MATHÉMATIQUE SUPÉRIEURE will be held each year during the summer, starting this next summer, at the University of Montreal, Montreal, Canada. The programme will include four courses: Professor Jacques L. Lions, University of Nancy, Problèmes aux limites dans les équations aux dérivées partielles; Professor Lucien Waelbroek, University of Brussels, Théorie des algèbres de Banach et des algèbres localement convexes; Professor Jean Maranda, University of Montreal, Introduction à I'algèbre homologique; Professor Maurice L'Abbé, University of Montreal, Théorie des fonctions récursives et applications métamathématiques. This seminar is specially intended for graduate students. Application may be made for financial assistance to cover all or part of travel and living expenses of those registered at the seminar. The registration fee is ten dollars. To obtain full information and registration forms, write to: Department of Mathematics, University of Montreal, P. O. Box 6128, Montreal, Quebec, Canada.

\section{THE 1963 SEMINAR AND CONGRESS}

The next seminar will be held at the University of Sa skatchewan, Saskatoon, in 1963. The central theme will be Combinatorial Mathematics and it is hoped that the seminar can be developed to attract a larger number of mathematicians from Canada and othe $r$ countries, in view of the important work being done in this field by Canadian mathematicians. Professor Gunter Pickert of TubingenLustnau, Germany has already accepted an invitation to be one of the research lecturers. There will also be other topics discussed at the seminar. Members are asked to send their suggestions regarding topics and lecturers to N.S. Mendelsohn, University of Manitoba, Chairman of the Seminar Committee. According to the new constitution a meeting of the Congress will be held biennially. Members are asked to send in their suggestions regarding duration of the Congress, topics for discussion, etc, to Professor W. L. G. Williams, Chairman of the Congress Committee, at the Secretariat. 